\title{
PRODUCTION AND CHARACTERIZATION OF COLLAGENASE FROM Bacillus sp. 6-2 ISOLATED FROM FISH LIQUID WASTE
}

\author{
Sartika $^{1 *}$, Hasnah Natsir ${ }^{2,3}$, Seniwati Dali ${ }^{2,3}$, Leliani $^{1}$ \\ ${ }^{1}$ Graduate Student, Magister Program of Chemistry, Mathematics and Natural Science Faculty, \\ Hasanuddin University, Perintis Kemerdekaan Street KM. 10 Tamalanrea, Makassar 90245, Indonesia \\ ${ }^{2}$ Laboratory of Biochemistry, Mathematics and Natural Science Faculty, Hasanuddin University, Perintis \\ Kemerdekaan Street KM. 10 Tamalanrea, Makassar 90245, Indonesia \\ ${ }^{3}$ Department of Chemistry, Mathematics and Natural Science Faculty, Hasanuddin University, Perintis \\ Kemerdekaan Street KM. 10 Tamalanrea, Makassar 90245, Indonesia \\ *Corresponding author: sartikassi14@gmail.com
}

\begin{abstract}
Abstrak. Kolagenase merupakan enzim yang mampu menghidrolisis kolagen utuh menjadi fragmen peptida kolagen. Kolagenase dan produk hidrolisisnya telah mendapat perhatian yang luar biasa dalam aplikasi medis dan industri. Penelitian ini dilakukan untuk mengisolasi dan mengidentifikasi bakteri penghasil kolagenase, kemudian memproduksi dan mengkarakterisasi kolagenase. Sebanyak 7 isolat dari limbah cair ikan diskrining pada media selektif mengandung $2 \%$ kolagen dan aktivitasnya dikonfirmasi melalui pembentukan zona bening. Isolat 6-2 positif sebagai penghasil kolagenase dan teridentifikasi sebagai Bacillus sp. 6-2 melalui karakteristik morfologi dan biokimia. Waktu fermentasi optimum enzim diselidiki. Ekstrak kasar kolagenase dikarakterisasi meliputi pengaruh $\mathrm{pH}$, suhu, dan ion-ion logam. Isolat 6-2 secara optimal memproduksi enzim kolagenase setelah inkubasi 30 jam dengan aktivitas $0.072 \mathrm{U} / \mathrm{mL}$ dan kadar protein $3.768 \mathrm{mg} / \mathrm{mL}$. pH dan suhu optimum adalah masing-masing 7.0 dan $40{ }^{\circ} \mathrm{C}$. Enzim diaktifkan oleh $\mathrm{Ca}^{2+}$ and $\mathrm{Mg}^{2+} 1 \mathrm{mM}$, dan dihambat oleh $\mathrm{Zn}^{2+}$ dan $\mathrm{Co}^{2+} 1 \mathrm{mM}$. Kolagenase dari Bacillus sp. 6-2 mungkin memiliki potensi untuk aplikasi medis dan industri.
\end{abstract}

Kata Kunci : kolagenase, kolagen, limbah cair ikan, Bacillus sp. 6-2, aktivitas

\begin{abstract}
Collagenases are enzyme that are able to hydrolyze native collagen into fragment collagen peptides. Collagenases and its hydrolysis products have received tremendous attention in medical and industrial applications. The present study was conducted to isolate and identify new collagenase producing bacteria from fish liquid waste, then produce and characterize collagenase. A total of 7 isolate from fish liquid waste were screened on selective medium containg $2 \%$ collagen and its activity was confirmed by the formation of clear zone. Isolate 6-2 was positif as collagenase producer and identified as Bacillus sp. 6-2 by morphological and biochemical characteristics. The optimum fermentation time of enzyme was investigated. Collagenase crude extract was characterized by the effect of $\mathrm{pH}$, temperature, and metal ions. Isolate 6-2 optimally produced collagenase enzyme after $30 \mathrm{~h}$ of incubation with activity of 0.072 $\mathrm{U} / \mathrm{mL}$ and protein content of $3.768 \mathrm{mg} / \mathrm{mL}$. The optimum $\mathrm{pH}$ and temperature were 7.0 and 40 ${ }^{\circ} \mathrm{C}$, respectively. The enzyme was activated by $1 \mathrm{mM} \mathrm{Ca}^{2+}$ and $\mathrm{Mg}^{2+}$, and inhibited by $1 \mathrm{mM} \mathrm{Zn^{2+ }}$ and $\mathrm{Co}^{2+}$. Collagenase from Bacillus sp. 6-2 may have potentials for medical and industrial applications.
\end{abstract}

Keywords : collagenase, collagen, fish liquid waste, Bacillus sp. 6-2, activity 


\section{INTRODUCTION}

Collagen is the most abundant structural protein in connective tissues and contributes about $30 \%$ of total proteins in mammals (Song $\mathrm{H}$, et al, 2017). Collagen consist of three $\alpha$ polypeptide chains that combine to form a triple helix structure in the ekstracellular matrix, Every chain contains hundreds of amino acids based on the Gly-X-Y residues ( $\mathrm{X}$ and $\mathrm{Y}$ are often proline and hydroxyproline). Since collagen is triple helix, it is hard to digest and resistant to most proteases (Hashim P, et al, 2015; Zhang Z, et al, 2005).

Collagenases are the only protease enzymes that hydrolyze peptide bonds in native collagen under various physiological conditions and break them into small fragments (Howes J.M, et al, 2015). Collagenases have been successfully applied in the food, cosmetic, pharmaceutical, and leather industries. Recently, they are also used for medical investigation, as therapeutic agents in some diseases, production of collagen hydrolysate, and have promising potential as diagnostic tools for autoimmune diseases (Alipour, $\mathrm{H}$, et al, 2016; Bousopha, S, et al, 2016; WenJia, P, et al, 2012). Collagen peptides, the product of collagen hydrolysis exhibit various biological activities of interest, such as antioxidant, anti-inflammatory, antitumor and antihypertensive, which may contribute to the prevention and treatment of diseases. They are widely used as ingredient in food, drinks, dietary supplement, functional food, and cosmetic (Song, H, \& Li, B, 20; Mohammad, A.W, 2014).

Collagenase have been isolated and characterized from bacterial cells and animal tissues. However, bacterial collagenases show high efficiency in hydrolizing collagen than mammals, can break down polypeptide chains at several sites in native and denatured collagen, producing small peptides (Alipour, H, et al, 2016). Bacterial collagenases have prospects for wider application in the future, so it is very interesting to study.

Fish liquid waste is a suitable habitat for growth of bacteria. The availability of protein substrates, mainly collagen offers a renewable sources of bacteria that can produce collagenase with novel characteristic for a broad application. Therefore, this study aims to isolate and identify collagenase producing bacteria from fish liquid waste, determine optimum production time and characterize collagenase.

\section{MATERIAL AND METHOD Instruments}

The instrument used include analytical scales, autoclave, incubator, shaking waterbath, spectronic 20D+, pipette micro, petri dish, and Erlenmeyer flask.

\section{Materials}

Some of the materials used are fish liquid waste, collagen, yeast extract, bacto peptone, bacto agar, $\mathrm{NaCl}, \mathrm{K}_{2} \mathrm{HPO}_{4}$, $\mathrm{MgSO}_{4} .7 \mathrm{H}_{2} \mathrm{O}$, Bovine Serum Albumin 
(BSA), tyrosine, Trichloroacetic Acid (TCA), $\mathrm{Na}_{2} \mathrm{CO}_{3}, \quad$ folin ciocalteu, aquades, and aquabides.

\section{Methods}

\section{Sample collection}

Samples of fish liquid waste were collected aseptically from the sewer in a local market, Makassar, Indonesia. Samples were kept in sterile bottles and transferred to the laboratory, stored at $4{ }^{\circ} \mathrm{C}$ until further use.

\section{Isolation and identification of collagenase producing bacteria}

Collagenase producing bacteria were isolated by serial dilution and pourplate method. Samples were serially diluted $\left(10^{-1}-10^{-6}\right)$ by sterile distilled water, and $\left(10^{-4}-10^{-6}\right)$ dilutions were poured on LA medium, incubated at $37{ }^{\circ} \mathrm{C}$ for $24 \mathrm{~h}$. Isolates were purified by the scratch method and screened on selective medium, then incubated at $37^{\circ} \mathrm{C}$ for $24 \mathrm{~h}$. Collagenase activity was confirmed by the formation of clear zone around the colonies. The isolate with the highest activity was identified by morphological and biochemical characteristics following Bergey's Manual of Systematic Bacteriology (Boone, D.R, et al, 2001).

\section{Preparation of inoculum}

The isolate was inoculated in 250 $\mathrm{mL}$ Erlenmeyer flasks containing $50 \mathrm{~mL}$ of a inoculum medium and incubated at $37{ }^{\circ} \mathrm{C}$ for $18-24 \mathrm{~h}$ with shaking at 180 rpm.

\section{Determination of the optimum production time of collagenase}

The culture (10\% of inoculum) was transferred into $250 \mathrm{~mL}$ Erlenmeyer flasks a containing $100 \mathrm{~mL}$ of fermentation medium and incubated at $37^{\circ} \mathrm{C}$ for $48 \mathrm{~h}$ with shaking at $180 \mathrm{rpm}$. Optical density (OD), collagenase activity and protein concentration were evaluated every $6 \mathrm{~h}$ to determine the optimum production time. OD was determined by measuring absorbance at $600 \mathrm{~nm}$. The culture medium was centrifuged at $3500 \mathrm{rpm}$ and $4{ }^{\circ} \mathrm{C}$ for 30 min, and the supernatants were collected as collagenase crude extracts.

\section{Determination of collagenase activity}

Collagenase activity was carried out according to the modified Bergmeyer's (1983) method with fish collagen as substrate. A reaction mixture, consisting of $0.5 \mathrm{~mL}$ of $1 \%$ collagen solution, $0.5 \mathrm{~mL}$ of $0.2 \mathrm{M}$ phosphate buffer ( $\mathrm{pH} 7.0)$ and $0.1 \mathrm{~mL}$ of enzyme was incubated at $37{ }^{\circ} \mathrm{C}$ for 10 min. Reaction was stopped by the addition of $1 \mathrm{~mL}$ of $0.1 \mathrm{M}$ TCA and incubated again at $37{ }^{\circ} \mathrm{C}$ for $10 \mathrm{~min}$, followed by centrifugation at 10.000 rpm and $4{ }^{\circ} \mathrm{C}$ for $10 \mathrm{~min}$. The supernatant $(0.75 \mathrm{~mL})$ was mixed with $2.5 \mathrm{~mL}$ of 0.4 $\mathrm{M} \mathrm{Na}_{2} \mathrm{CO}_{3}$ and $0.5 \mathrm{~mL}$ of Folin Ciocalteau. The mixture was incubated at $37^{\circ} \mathrm{C}$ for $20 \mathrm{~min}$ and measured at $\lambda 578$ $\mathrm{nm}$ by spectronic 20D+ (Thermo). Tyrosine $(5 \mathrm{Mm})$ was used as standard. One unit (U) of enzyme activity was defined as enzyme which produces 1 $\mu$ mol of tyrosine per min. The specific activity was calculated as the ratio of the enzymatic activity to the total 
protein content of the sample, and expressed in $\mathrm{U} / \mathrm{mg}$.

\section{Determination of proteint concentration}

Protein concentration of collagenase crude extracts was determined by Lowry method, using bovine serum albumin (BSA) as the standard.

\section{Characterization collagenase}

of

The effect of $\mathrm{pH}$, temperature, and metal ion on enzyme activity was investigated by determining enzyme activity at various $\mathrm{pHs}(6.0,6.5,7.0,7.5$, and 8.0), temperatures $(30,35,37,40$, 45 , and $50{ }^{\circ} \mathrm{C}$ ), and the presence of metal ions $\left(\mathrm{MgSO}_{4}, \mathrm{CaCl}_{2}, \mathrm{ZnCl}_{2}\right.$, and $\mathrm{CoCl}_{2}$ : $1 \mathrm{Mm}$ and $5 \mathrm{mM}$ ). The $\mathrm{pH}$ was adjusted using $0.2 \mathrm{M}$ phosphate buffer and the enzyme activity was determined as described in section 5 .

\section{RESULT AND DISCUSSION}

1. Isolation and identification of collagenase producing bacteria
In the present study, a total of 7 isolate were successfully isolated from fish liquid waste collected from local market, Makassar, Indonesia. They were screened for collagenolitic activity on selective medium containing $2 \%$ collagen, and the isolate 6-2 was found as the only collagenase producer. Collagenolitic activity was indicated by the presence clear zone around colonies (Figure 1). The clear zone was formed by secretion of collagenase enzyme to break down the collagen substrat into small fragments. Morphological and biochemical characteristics of the isolate 6-2 are presented in Table 1 and 2, respectively. According to Bergey's Manual of Systematic Bacteriology, isolate 6-2 had similarities with Bacillus genus. For next, the isolate was be Bacillus sp. 6-2. Bacillus had been reported as collagenase producers among them are $B$. cereus $M B L 13, B$. pumilus Col-J, B. licheniformis F11.4 and $B$. KM369985 (Liu, L, et al, 2010; $\mathrm{Wu}$, Q, et al, 2010; Baehaki, A, et al, 2012; Savita, K \& Arachana, P, 2015). This result proved that fish liquid waste are suitable habitat for growth of collagenase producing bacteria.

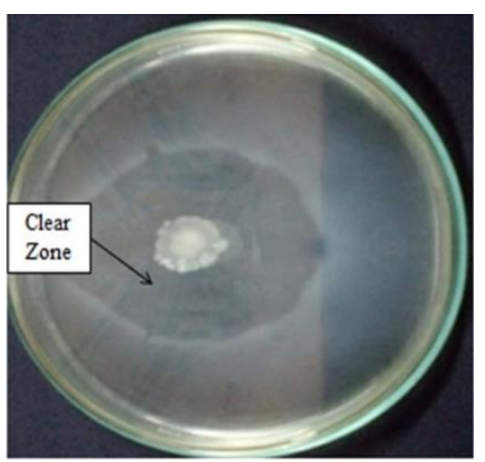

Figure 1. Collagenase activity of isolate 6-2 on selective medium 
Table 1. Morphological Characteristics

\begin{tabular}{|c|c|c|}
\hline \multicolumn{2}{|c|}{ Parameter Test } & Remark \\
\hline \multirow{5}{*}{ Macroscopic } & Colony form & Circular \\
\hline & $\begin{array}{l}\text { The edge of the } \\
\text { colony }\end{array}$ & Undulate \\
\hline & Surface & Rude \\
\hline & Elevation & Convex \\
\hline & Color & White \\
\hline \multirow{3}{*}{ Microscopic } & Gram stain & Positive \\
\hline & Cell form & Rod \\
\hline & Spore & Spore forming \\
\hline
\end{tabular}

Table 2. Biochemical Characteristics

\begin{tabular}{|c|c|c|}
\hline \multicolumn{2}{|c|}{ Parameter Test } & Remark \\
\hline \multirow{3}{*}{ TSIA } & Acid formation & Positive \\
\hline & Gas formation & Negative \\
\hline & $\mathrm{H}_{2} \mathrm{~S}$ formation & Negative \\
\hline \multirow{3}{*}{ SIM } & Indol formation & Negative \\
\hline & Motility & Negative \\
\hline & $\mathrm{H}_{2} \mathrm{~S}$ formation & Negative \\
\hline \multirow{2}{*}{ MR-VP } & Metyl Red & Positive \\
\hline & Voges Proskauer & Negative \\
\hline Urease & & Negative \\
\hline Citrat & & Negative \\
\hline \multirow{4}{*}{ Fermentation of carbohydrate } & Glucose & Negative \\
\hline & Lactose & Negative \\
\hline & Sucrose & Positive \\
\hline & Mannitol & Negative \\
\hline
\end{tabular}

\section{Determination of the optimum}

production time of
collagenase

Collagenase enzymes was produced in fermentation medium containing $2 \%$ collagen for $48 \mathrm{~h}$. Figure 2 reports the time course of collagenase production by Bacillus sp. 6-2 .The activity of collagenase was detected in the culture medium since the beginning of adaptation phase, and significantly increased in the exponential phase until optimum after $30 \mathrm{~h}$ of incubation. Hence, the optimum production time was $30 \mathrm{~h}$ with collagenase activity of $0.072 \mathrm{U} / \mathrm{mL}$ and protein concentration of 3.768 $\mathrm{mg} / \mathrm{mL}$. This is similar to Pseudomonas $\mathrm{sp}$, which optimally produce collagenase in the exponential phase (Gautam, M \& Azmi, W, 2017). However, the optimum production time of collagenase by microorganisms can be different because 
it is influenced by several factors such as

and temperatures (Chauhan, A \& medium component, inoculum size, $\mathrm{pH}$, Prabha, V, 2017).

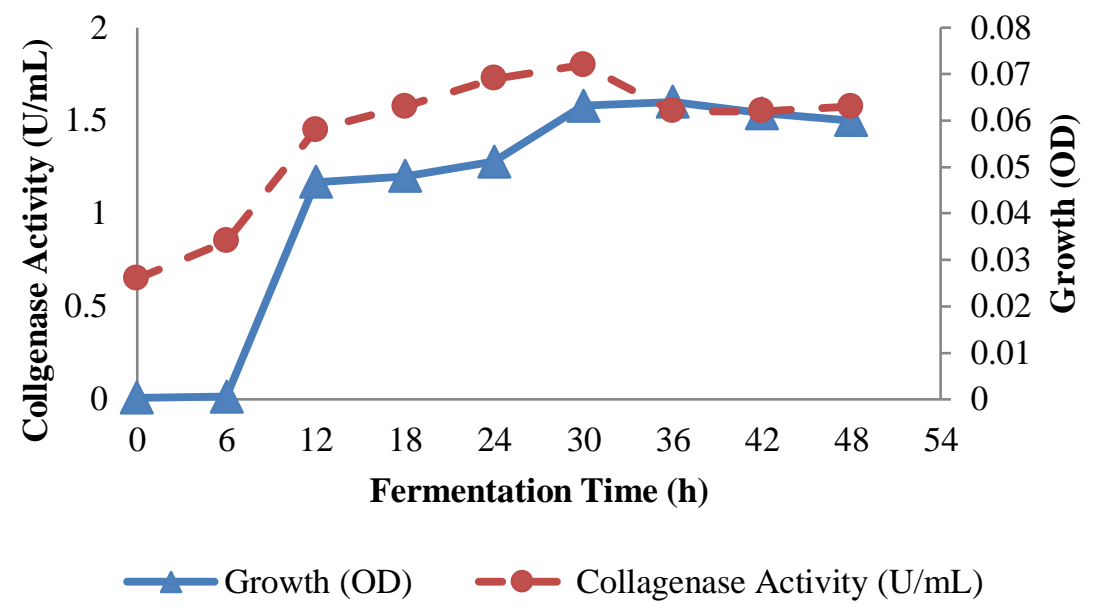

Figure 2. The time course of collagenase production by Bacillus sp. 6-2 in medium containing $2 \%$ collagen, at $\mathrm{pH} 7.0$ and temperature $40{ }^{\circ} \mathrm{C}$

3. Characterization

of collagenase

\subsection{The effect of $\mathrm{pH}$}

Enzyme activity was determined at various $\mathrm{pHs}(6.0,6.5,7.0,7.5$, and 8.0 ), at $37{ }^{\circ} \mathrm{C}$ using $0.2 \mathrm{M}$ phosphate buffer to adjusted $\mathrm{pH}$. The results of the effect of $\mathrm{pH}$ on enzyme activity are shown in Figure 3. The optimum activity of the enzyme was observed at $\mathrm{pH}$ 7.0, with levels of $\quad 0.072 \mathrm{U} / \mathrm{mL}$. Enzyme activity increases at $\mathrm{pH}$ 6.0-7.0, and decreases at $\mathrm{pH}$ 7.5-8.0. The $\mathrm{pH}$ of medium affects enzyme activity. The three-dimensional structure of enzyme depends on $\mathrm{pH}$. A lower or higher pHs causes folding so that activity decreases. In addition, ionic groups in the active sites of the enzyme must be in a stable form. The variations in $\mathrm{pH}$ of the medium cause ionic shape changes which affect the reaction (Bhunia, B, et al, 2013). The optimum $\mathrm{pH}$ of collagenase produced by Bacillus sp. 62 is neutral, similar to collagenase from B.licheniformis $\mathrm{F} 11.4$, but lower than $\mathrm{pH}$ 8.0 of B.cereus MBL3, and $\mathrm{pH} 9.0$ of Penicillium sp. UCP 1286 (Baehaki, A, et al, 2012; Liu, L, et al, 2010; Wanderleya, M.C.D.A, et al, 2017).

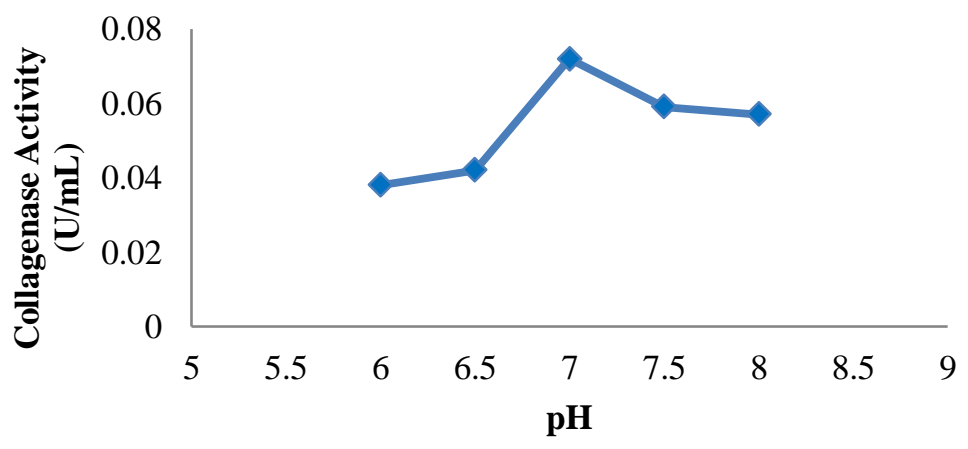


Figure 3. Effects of $\mathrm{pH}$ on collagenase activity at $37{ }^{\circ} \mathrm{C}$ using $0.2 \mathrm{M}$ phosphate buffer

\subsection{The effect of temperature}

Enzyme activity was determined at various temperatures $(30,35,37,40$, 45 , and $50{ }^{\circ} \mathrm{C}$ ), at $\mathrm{pH} 7.0$ (using $0.2 \mathrm{M}$ phoshate buffer). The results of the effect of temperatures on enzyme activity are shown in Figure 4. The optimum activity of the enzyme was observed at $40{ }^{\circ} \mathrm{C}$, with levels of 0.092 $\mathrm{U} / \mathrm{mL}$. Enzyme activity significantly increased at $30-40{ }^{\circ} \mathrm{C}$, then dramatically decreased at $45{ }^{\circ} \mathrm{C}$. The rection is slow at low temperatures. But at higher temperatures, denaturation occurs causing decreased enzyme activity. Thus, the optimum temperatures of collagenase produced by Bacillus sp. 62 was reached at $40{ }^{\circ} \mathrm{C}$. This result is similar to collagenase from $B$. cereus MBL3, but higher than most collagenase that have been reported (Wanderleya, M.C.D.A, et al, 2017; Liu, L, et al, 2010; Bhunia, B, et al, 2013; Kang, S.I, et al, 2005).

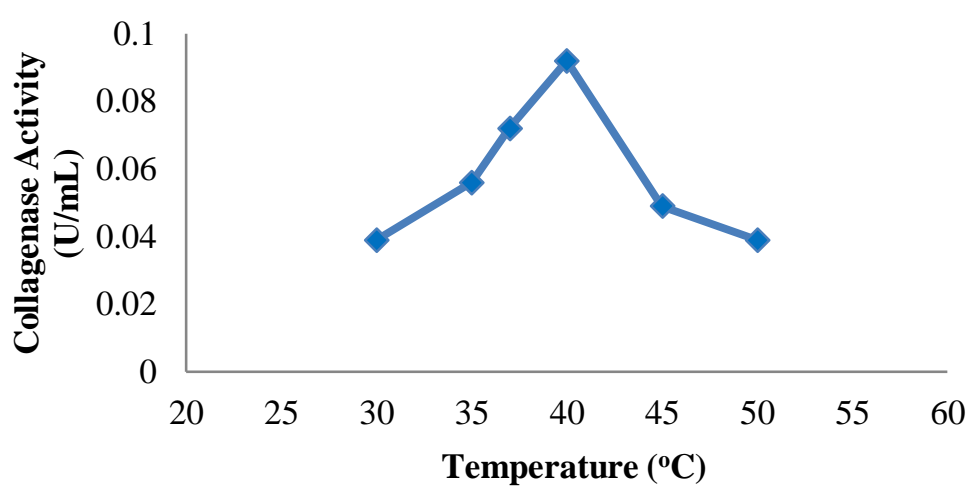

Figure 4. Effects of temperature on collagenase activity at $\mathrm{PH} 7$ using $0.2 \mathrm{M}$ phoshate buffer

\subsection{The effect of metal ions}

Enzyme activity was determined by the presence of metal ions $\left(\mathrm{MgSO}_{4}\right.$, $\mathrm{CaCl}_{2}, \mathrm{ZnCl}_{2}$, and $\mathrm{CoCl}_{2}: 1 \mathrm{Mm}$ and 5 $\mathrm{mM}$ ) at $\mathrm{pH} 7.0$ and $40{ }^{\circ} \mathrm{C}$, using $0.2 \mathrm{M}$ phosphate buffer to adjusted $\mathrm{pH}$. Enzyme activity without metal ions was considered as control (100\%). The results of the effect metal ions on enzyme activity are shown in Figure 5.

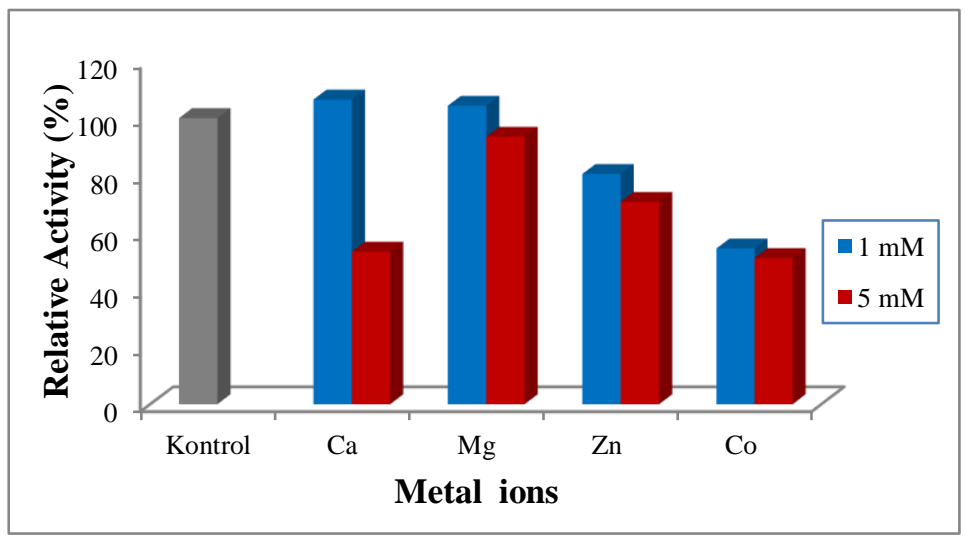


Figure 5. The effects of metal ions on collagenase activity at $\mathrm{pH} 7.0$ and temperature $\left(37^{\circ} \mathrm{C}\right)$.

Some collagenases depend on metal ions for their catalytic activity, they are from the metalloprotease group. Metal ions are needed at active sites as activator or inhibitor in catalyzing substrate at the certain concentration [21,29]. The effect of metal ions on collagenase activity from Bacillus sp. 62 was studied using several divalent metals such as $\mathrm{MgSO}_{4}, \mathrm{CaCl}_{2}, \mathrm{ZnCl}_{2}$, and $\mathrm{CoCl}_{2}$. The results showed that the presence of $\mathrm{Mg}^{2+}$ and $\mathrm{Ca}^{2+} 1 \mathrm{mM}$ increased enzyme activity by $6.52 \%$ and $4.35 \%$ respectively, but the presence of up to $5 \mathrm{mM}$ caused a decrease in activity. Whereas $\mathrm{Zn}^{2+}$ and $\mathrm{Co}^{2+} 1 \mathrm{Mm}$ and $5 \mathrm{mM}$ strongly inhibited actvity. $\mathrm{Mg}^{2+}$ and $\mathrm{Ca}$ ${ }^{2+}$ with different concentrations give different effects, this can be explained by the concept that activator compounds up to a certain amount can improve the catalytic function of enzyme, but the excess amount of the activator can cause the competition of the free activator and the activator substrate complex to enzyme. The excess amount of the free activator causes the competitive inhibition (Natsir, H, et al, 2013). However, collagenase produced by Bacillus sp. 6-2 was activated by $1 \mathrm{mM}$ $\mathrm{Mg}^{2+}$ and $\mathrm{Ca}^{2+}$, and inhibited by $1 \mathrm{mM}$ $\mathrm{Zn}^{2+}$ and $\mathrm{Co}^{2+}$.

\section{CONCLUSION}

A total of 7 isolate were obtained from fish liquid waste collected from local market, Makassar, Indonesia. One Isolate was found as collagenase producer and identified as Bacillus sp. 62. The isolate optimally produced collagenase enzyme after $30 \mathrm{~h}$ of incubation with activity of $0.072 \mathrm{U} / \mathrm{mL}$ and protein concentration of 3.768 $\mathrm{mg} / \mathrm{mL}$. The optimum $\mathrm{pH}$ and temperature were 7.0 and $40{ }^{\circ} \mathrm{C}$, respectively. The enzyme was activated by $1 \mathrm{mM} \mathrm{Mg}{ }^{2+}$ and $\mathrm{Ca}^{2+}$, and inhibited by $\quad 1 \mathrm{mM} \mathrm{Zn}^{2+}$ and $\mathrm{Co}^{2+}$. Futher research is needed to find out the spesific application, but it may have potentials for medical and industrial applications.

\section{REFERENCES}

Alipour, H., Raz, A., Zakeri, S., and Djadid, N.D. 2016. Therapeutic Applications of Collagenase (Metalloproteases): A Review. Asian Pac J Trop Biomed; 6 (11); 975-981.

Baehaki, A., Suhartono, M.T., Sukarno, Syah, D., Sitanggang, A.B., Setyahadi, S., and Meinhardt, F. 2012. Purification and Characterization of Collagenase from Bacillus licheniformis F11.4. AJMR; 6 (10); 23732379.

Bergmeyer, H.U. 1983. Methods of Enzymatic Analysis, Vol 2. Germany: Verlag Chemie. 1983.

Bhunia, B., Basak, B., Mandal, T., Bhattacharya, P., and Dey, A. 2013. Effect of $\mathrm{pH}$ and Temperature on Stability and Kinetics of Novel Extracellular Serine Alkaline Protease (70 kDa). Int. J. Biol. Macromol; 54; 1-8.

Bousopha, S., Nalinanon, S., and Sriket, C. 2016. Production of Collagen Hydrolysate with Antioxidant Activity from Pharaoh Cuttlefish Skin. CMU J. Nat. Sci; 15 (2); 151-162. 
Chauhan, A., and Prabha, V. 2017. Production and Partial Purification of Collagenase from Bacillus sp. Isolated from Soil Sample. Int J Adv Res; 2 (5); 6065.

Gautam, M., and Azmi, W. 2017. Screening and Isolation of Collagenase Producing Microorganism from Proteins Waste Found in Himalayan Region. JABR; 4 (1); 558-565.

Hashim, P., Ridzwan, M.M.S., Bakar, J., and Hashim, D.M. 2015. Collagen in Food and Beverage Industries. IFRJ; 22 (1); 1-8.

Howes, J.M., Pugh, N., Knäuper, V., and Farndale R.W. 2015. Modified platelet deposition on matrix metalloproteinase 13 digested collagen I. J Thromb Haemost; 13(12); 2253-2259.

Kang, S.I., Jang, Y.B., Choi, Y.J., and Kong, J.Y. 2005. Purification and Properties of a Collagenolytic Produced by Marine Bacterium Vibrio vulnificus CYK279H. Biotechnol. Bioprocess Eng; 10; 593-598.

Liu, L., Ma, M., Cai, Z., Yang, X., and Wang, W. 2010. Purification and Properties of a Collagenolytic Protease Produced by Bacillus cereus MBL13 Strain. Food Technol. Biotechnol; 48 (2); 151-160.

Lowry, O.H., Rosebrough, N.J., Farr, A.I., and Randall. 1951. Protein Measurement with the Folin Phenol Reagen. J.Biol.Chem; 193; 265-275.

Mohammad, A. W. 2014. Process for Production of Hydrolysed Collagen from Agriculture Resources: Potential for Further Development. J. Applied Sci; 14 (12); 1319-1323.
Natsir, H., Patong, R., Suhartono, M.T., and Ahmad, A. 2013. Isolation and Purification of Thermostable Chitinase Bacillus licheniformis Strain HSA3-1a from Sulili Hot Spring in South Sulawesi, Indonesia. Int J Pharm Bio Sci; 4 (3); 1252-1259.

Savita, K., and Arachana, P. 2015. Production of Collagenase by Bacillus KM369985 Isolated from Leather Sample. Int. J. Res. Biosciences; 4 (4); 81-87.Song, H., and Li, B. 2017. Beneficial Effects of Collagen Hydrolysate: A Review on Recent Developments. Biomed $J$ Sci \& Tech Res; 1 (2); 1-4.

Wanderleya, M.C.D.A., Neto, J.M.W.D., Albuquerqueb, W.W.C., Marques, D.D.A.V., Lima, C.D.A., Silverio, S.I.D.C., Filho, J.L.D.L., Teixeira, J.A.C., and Porto, A.L.F. 2017. Purification and Characterization of A Collagenase from Penicillium sp. UCP 1286 by Polyethylene Glycol-Phosphate Aqueous Two-Phase System. Protein Expr. Purif; 133; 8-14.

Wen-Jia, P., Jun-Wei, Y., Ya-Nan W, et al. 2012. Matrix metalloproteinases: a review of their structure and role in systemic sclerosis. $J$ Clin Immunol.; 32(6); 1-4.

Wu, Q., Li, C., Li, C., Chen, H., and Shuliang, L. 2010. Purification and Characterization of a Novel Collagenase from Bacillus pumilus Col-J. Appl Biochem Biotechnol; 160; 129-139.

Zhang, Z., Li, G., and Shi, B. 2005. Physicochemical properties of collagen, gelatin and collagen hydrolysate derived from bovine limed split wastes. J.Soc.Leather Technol. Chem; 90; 23-28. 